\title{
Increase of lipids during HCV treatment: virus action or medication?
}

\author{
Vanessa Gutierrez de ANDRADE, Fabio da Silva YAMASHIRO, Cassio Vieira OLIVEIRA, \\ Leticia Lastória KUROZAWA, Alecsandro MOREIRA and Giovanni Faria SILVA
}

Received 13/11/2017

Accepted 9/1/2018

\begin{abstract}
Background - The interaction between serum lipids and C virus infection is well known, as are serum lipid levels in the Peg-IFN / RBV-based treatment. However, with direct action antivirals (DAAs) this behavior is still unclear. Objective - To compare serum lipids levels between patients treated with Peg-IFN/RBV and DAAs and to evaluate lipids in sustained virological response (SVR) with DAAs. Methods - Retro prospective study comparing the behavior of total cholesterol (TC), low-density lipoprotein (LDL) and triglycerides (TG) serum levels during treatment with DAAs (G-DAAs) and a control historic group Peg-IFN/RBV (G-PR). Coorte, prospective study, to study the behavior of lipids in the SVR with DAAs. Data were collected at the beginning of treatment (baseline: t-base) and at week 12 of treatment (t-12) for G-DAAs and at week 24 (t-24) for G-PR, groups. In the cohort evaluation, the samples at t-base and at week 12 after the end of treatment (t-SVR). Delta lipids: difference between lipids in t-12 / t-24 minus t-base for comparison between G-PR and G-AADs groups and t-SVR minus t-base for lipid analysis in SVR. Analysis with Kruskal Wallis and Wilcoxon tests to compare the delta lipids of the groups. The $P$ value was 0.05 . Results - In the assessment between G-PR and G-DAAs groups, we included 63 and 121 patients, respectively. The groups did not differ one from the other (BMI, sex, genotype, fibrosis, total cholesterol, LDL, and TG) except by age ( $50.38 \pm 10.44$ vs $56 \pm 9.69, P=0.0006)$. We observed a decrease in levels of TC and LDL and an increase in TG, in G-PR, and in G-DAAs the opposite ( $\Delta$ TC $-13.9 \pm 34.5$ vs $4.12 \pm 34.3 P=0.0005, \Delta$ LDL $-7.16 \pm 32$ vs $10.13 \pm 29.92, P=0.003, \Delta$ TG $4.51 \pm 53.7$ vs $-8.24 \pm 49.93$, $P=0.0025)$. In the coorte analysis, we included 102 patients, $70 \%$ men and $56 \% \mathrm{~F} 4,95$ of them reached SVR. We observed an increase of TC and LDL and a decrease of TG in both groups (SVR and non SVR), with no statistical difference ( $\triangle \mathrm{TC} P=0.68 ; \Delta \mathrm{LDL} P=0.69 ; \Delta \mathrm{TG} \mathrm{P}=0.43$ ). We did not find significant difference in delta evaluation by genotype 1 and $3(\Delta \mathrm{TC}+29.7 \pm 40.2 \mathrm{vs}+13.4 \pm 30.3, P=0.06 ; \Delta \mathrm{LDL}+21.4 \pm 28.6 \mathrm{vs}+16.6 \pm 31.3, P=0.41 ;$ $\Delta$ TG $-3.6 \pm 60.6$ vs $-0.7 \pm 40, P=0.91)$. Conclusion - Serum lipids level differed during treatment with Peg-IFN and DAAs. Treatment with DAAs was associated with an increase of TC and LDL and a decrease of TG, independently of SVR.
\end{abstract}

HEADINGS - Hepatitis C. Lipid metabolism. Virological analysis. Interferon-alpha. Antiviral agents, therapeutic use.

\section{INTRODUCTION}

Hepatitis $\mathrm{C}$ virus (HCV) infection is a serious public health problem, that infects approximately 170 million people worldwide ${ }^{(1)}$. It remains the leading cause of death from liver disease and, despite recent medical advances in HCV therapy, it is still the principal indication for liver transplantation in the United States ${ }^{(2,3)}$. Eighty-five percent of people who are infected fail to achieve clearance of the virus and become chronically infected ${ }^{(4)}$. Hepatic cirrhosis will be developed by $20 \%$ of them within about 20 years. In the cirrhotic patients, $6 \%$ will develop terminal hepatic disease, and $4 \%$ will develop hepatocellular carcinoma (HCC) per year ${ }^{(5,6)}$.

Chronic Hepatitis C (CHC) has shown an interaction with lipids, and it is associated with hepatic steatosis and serious lipids changes, beside that the lipids participate actively in viral replication $^{(7,8)}$. To facilitate viral assembly and production, HCV proteins interact with lipidic droplets by associating themselves with lowdensity lipoproteins (LDL) called "lipoviric" particles (LPV). The incorporation of host apolipoproteins into the LVP could be a mechanism to facilitate the HCV entry in the hepatocyte(8,9). Viral assembly and production of infective particles requires many apolipoproteins ${ }^{(10,11)}$. Moreover, elevated serum lipid levels have been associated with the rate of sustained viral response (SVR) to pegylated interferon and ribavirin (Peg-IFN/RBV) therapy for chronic HCV-infected patients ${ }^{(12,13)}$. So, there are many facts showing a connection between $\mathrm{HCV}$ infection and lipids.

HCV eradication with Peg-IFN/RBV was associated with serum lipid alterations. Shao Quing et al.(14), and Ramcharam et al. ${ }^{(12)}$, observed a decrease of total cholesterol (TC) and LDL and an increase of triglycerides (TG) during the treatment; further Corey et al. ${ }^{(15)}$, observed that the levels of TC and LDL increased in post-treatment, but without significant changes in relation to TG. Recently, in the post-interferon era, Meissner et al. ${ }^{(16)}$, showed that the patients with HCC genotype (GTP), one treated with sofosbuvir and ribavirin had an increase in serum LDL and a decrease in serum TG. However, these results are not quite clear yet.

Declared conflict of interest of all authors: none

Supported by Vanessa Gutierrez de Andrade CNPq scholarship.

The study was performed on Clinical Medical Department, in Botucatu Medical School.

Universidade Estadual Paulista 'Júlio de Mesquita Filho' (UNESP), Campus Botucatu, Faculdade de Medicina, Departamento de Clínica Médica, Botucatu, SP, Brasil.

Corresponding author: Giovanni Faria Silva. E-mail: giovanni@fmb.unesp.br 
Therefore, the purposes of the present study were to compare the TC, LDL, and TG serum levels (during the treatment period) of one historic group of patients treated with Peg-IFN/RBV with another group of patients treated with direct-acting antivirals (DAAs) and assess the behavior of serum levels of these lipids with the SVR in patients treated with DAAs.

\section{METHODS}

This was a retro prospective study in which we assessed a historic control of 63 patients treated with Peg-IFN/RBV (G-PR) from 2010 to 2013 and, prospectively, 121 patients treated with DAAs (GDAAs) from 2015 to 2017. The study was done at the Viral Hepatitis Outpatient Clinic of Botucatu Medical School and approved by the Committee on Ethics in Research of the Botucatu Medical School (1.851.631). Data were collected at the beginning of treatment (baseline: t-base) and, in the twelfth week of treatment (t-12) for GDAAs and in the twenty-fourth week of treatment (t-24) for G-PR to perform comparative analysis between these two groups. In the cohort assessment, to study lipids and SVR behavior in G-DAAs, we included 102 patients. The samples were collected in t-base and in the twelfth week after the end of treatment (t-SVR). The criteria of inclusion were: chronic hepatitis $\mathrm{C}$ infection (presence of RNA$\mathrm{HCV}$ ); age $\geq 18$ years-old; patients who received anti-HCV drugs; and the samples collected during the periods set by the study. The criteria of exclusion were as follow: HBV and/or HIV co-infection; hepatocellular carcinoma in patient's record; and patients with transplant (liver and kidney transplants). Fibrosis was assessed through hepatic elastography or biopsy (METAVIR classification). Cirrhosis could be determined by the clinic or imaging examination. To determine DELTA lipids value, the difference was calculated between lipids at $\mathrm{t}-12 / \mathrm{t}-24$ minus lipids in t-base, for G-DAAs and G-PR, respectively. Therefore, comparison between G-PR and G-DAAs groups could be made. In the assessment of the behavior of lipids with SVR, the calculation was made by calculating t-SVR minus t-base. Descriptive statistical analysis, non-parametric Kruskal Wallis, and Wilcoxon tests were performed to establish comparison of DELTA lipids between the groups and to set associative analysis for comparison between G-PR and G-DAAs groups. To measure the SVR influence in lipids, we used non-parametric tests. The value of $P$ considered for both samples was $<0.05$.

\section{RESULTS}

In the assessment between G-PR and G-DAAs groups, we included 63 and 121 patients, respectively. The groups did not differ one from the other (BMI, sex, genotype, fibrosis, total cholesterol, LDL, and TG) except by age (TABLE 1).

TABLE 2 shows the analysis comparing DELTA lipids ( $t-12$ or $\mathrm{t}-24$ minus t-base) between the two groups. The behavior of serum lipid levels during anti viral treatment differed from one another.

In the cohort analysis, when we were evaluating lipids and SVR behaviors in the group treated with DAAs, we included 102 patients, $70 \%$ male, age $56 \pm 9$ years, BMI $27.01 \pm 5.09$, fibrosis $\leq \mathrm{F} 2$ $35(34 \%)$, F3 $10(10 \%)$, and F4 $57(56 \%)$. Most of them $(93 \%$, 95/102) reached SVR.

TABLE 3 shows the distribution of lipids in t-base, t-SVR, and DELTA according to SVR or non-SVR variables. We observed TC and LDL increases and a TG decrease in both groups (SVR and non-SVR); however, we did not observe a statistical difference between them (DELTA TC $P=0.68$; DELTA LDL $P=0.69$; DELTA TG $P=0.43$ ).

TABLE 1. Descriptive analysis of baseline samples (t-base) by group.

\begin{tabular}{lccc}
\hline & G-PR $(\mathbf{n}=63)$ & G-DAAs $(\mathbf{n}=121)$ & $P$ \\
\hline Age & $50.3 \pm 10.4$ & $56 \pm 9.6$ & 0.0006 \\
BMI & $26.7 \pm 4.6$ & $28 \pm 5.8$ & 0.23 \\
Men(\%) & 51.6 & 67.6 & 0.05 \\
GTP1/GTP2/GTP3n $(\%)$ & $41(66) / 1(2) / 20(32)$ & $76(77) / 3(3) / 20(20)$ & 0.25 \\
F 2 F3/F4 n(\%) & $25(40) / 10(16) / 27(44)$ & $35(35) / 9(9) / 55(56)$ & 0.29 \\
TC & $160.1 \pm 34$ & $151 \pm 36.8$ & 0.12 \\
LDL & $87.7 \pm 30$ & $78.1 \pm 31.3$ & 0.05 \\
TG & $115.4 \pm 58.6$ & $103.1 \pm 48.9$ & 0.11 \\
\hline
\end{tabular}

BMI: body mass index, GTP: genotype, F: fibrosis, TC: total cholesterol, LDL: low-density lipoprotein, TG: triglycerides.

TABLE 2. Comparative analysis between lipid DELTAs by the treatment group.

\begin{tabular}{lccc}
\hline & G-PR & G-DAAs & \multicolumn{1}{c}{} \\
\hline DELTA TC & $-13.9 \pm 34.5$ & $+4.1 \pm 34.3$ & 0.0005 \\
DELTA LDL & $-7.1 \pm 32$ & $+10.1 \pm 29.9$ & 0.0003 \\
DELTA TG & $+4.5 \pm 53.7$ & $-8.2 \pm 49.9$ & 0.0025 \\
\hline
\end{tabular}

DELTA: $\mathrm{t}-12$ / $\mathrm{t}-24$ minus $\mathrm{t}$-base for G-DAAs and G-PR.

TABLE 3. Distribution of serum lipids in t-base and t-SVR in the SVR and non SVR groups.

\begin{tabular}{lcccccc}
\hline & TC & TC & LDL & LDL & TG & TG \\
& SVR & Non SVR & SVR & Non SVR & SVR & Non SVR \\
\hline t-base & $152 \pm 37$ & $125.8 \pm 10$ & $79.7 \pm 32.3$ & $60.1 \pm 9.4$ & $103.8 \pm 53.4$ & $130.2 \pm 118.4$ \\
t-RVS & $169 \pm 42.6$ & $143 \pm 23.7$ & $97.1 \pm 36$ & $79.7 \pm 15.6$ & $100.8 \pm 47.4$ & $125.6 \pm 45.2$ \\
DELTA & $+16.3 \pm 33^{*}$ & $+17.2 \pm 22.3^{*}$ & $+17.4 \pm 31 \dagger$ & $+19.5 \pm 19.6 \dagger$ & $-3 \pm 55.5 \Delta$ & $-4.6 \pm 93.4 \Delta$ \\
\hline
\end{tabular}

DELTA: t-SVR minus t-base, TC: total cholesterol, LDL: low-density lipoprotrein, TG: triglycerides, ${ }^{*} P$-value of DELTA TC (SVR $v s$ non SVR) $=0.68$, $\dagger P$-value of DELTA LDL (SVR vs non SVR $)=0.69, P$-value of DELTA TG $($ SVR vs non SVR $)=0.43$. 
TABLE 4, shows the serum levels of lipids distributed by genotype and excluded from analysis genotype 2 (two patients). We did not observe a statistical difference in DELTA lipids between the categorized genotypes.

TABLE 4. Distribution of serum lipids in t-base and t-SVR, categorized by genotype.

\begin{tabular}{lccc}
\hline & TC & LDL & TG \\
\hline Genotype 1 $\mathrm{n}=82$ & & & \\
t-base & $155.7 \pm 34.4$ & $80.8 \pm 31.8$ & $108.1 \pm 58.4$ \\
t-SVR & $169.2 \pm 41$ & $97.5 \pm 35.5$ & $104.5 \pm 49.2$ \\
DELTA & $+13.4 \pm 30.3$ & $+16.6 \pm 31.3$ & $-3.6 \pm 60.6$ \\
Genotype 3 $\mathrm{n}=18$ & & & \\
t-base & $131.2 \pm 43.7$ & $69.1 \pm 30.8$ & $91.1 \pm 52.9$ \\
t-SVR & $160.9 \pm 47.8$ & $90.5 \pm 35.5$ & $90.4 \pm 37.1$ \\
DELTA & $+29.7 \pm 40.2$ & $+21.4 \pm 28.6$ & $-0.7 \pm 40$ \\
$P$ & 0.06 & 0.41 & 0.91 \\
\hline
\end{tabular}

DELTA: t-SVR minus t-base, TC: total cholesterol, LDL: low-density lipoprotrein, TG: triglycerides.

\section{DISCUSSION}

The interaction between serum lipids and infection by the $\mathrm{C}$ virus is already well-acknowledged, as is the serum levels behavior of those during the treatment with Peg-IFN/RBV. Nevertheless, with DAAs, this behavior is still not clear. Some studies of lipid behavior with Peg-IFN/RBV showed that TC and LDL levels decrease during treatment, whereas triglyceride levels tend to increase ${ }^{(12,14)}$. On the other hand, other study reported a lipid increase in posttreatment ${ }^{(15)}$. Concerning DAAs, recent studies suggest that TC and LDL serum levels increase after the end of treatment, whereas triglyceride levels decrease ${ }^{(16,17,18,19)}$. However, the behavior of serum levels along with the sustained virologic response is not yet clear, that is, whether the relapse or the non-response to treatment could be accompanied by these lipidic alterations. In comparing the treatment between the two groups (G-PR and G-DAAs), we observed a decrease in TC and LDL levels and an increase of triglycerides in G-PR whereas an increase in TC and LDL levels and a decrease of triglycerides was observed in G-DAAs.

Darmendra Ramcharran et al. ${ }^{(12)}$, when evaluating 330 genotype-1 patients treated with Peg-INF/RBV, observed increased levels of TG and decreased levels of LDL and TC $(P>0.0001)$ during the first 24 weeks of treatment. The authors also report that the amount of prescription medication was related to these lipidic alterations. Another study, assessing Chinese patients treated with Peg-IFN/R, genotype $1^{(14)}$, noted that serum lipids (TC and TG) decreased during treatment; these alterations were persistent only in patients that reached SVR. Corey et al. ${ }^{(15)}$, in evaluating 87 subjects, observed that those who reached SVR presented reduced TC and LDL levels in post-treatment compared with baseline. More recently, studies show an increase of TC and LDL levels during treatment with DAAs ${ }^{(17,18)}$, as we observed. Meissner et al. ${ }^{(16)}$, and Mark et al. ${ }^{(19)}$, also observed a decrease in TG serum levels, as we observed as well.

In our study, we observed an increase of TC and LDL and a decrease of TG regardless of the reach of SVR. Meissner et al. ${ }^{(16)}$, in assessing 55 naive patients (GTP 1) treated with sofosbuvir and ribavirin, found an increase of LDL and a decrease of TG in post-treatment, regardless of the treatment result. However, no significant changes were found in TC.

In our study, patients who reached SVR had more elevated serum levels of TC and LDL in baseline than those subjects who did not reach SVR, but we did not find any substantial difference between the two groups, SVR and non SVR (data not shown), probably because of the great dispersion in the results and the small number of patients who did not reach SVR. In addition, we did not observe any substantial difference among the DELTA lipids: $p$ delta TC (0.68), $P$ delta LDL (0.69) and p delta TG (0.43). In Progress study ${ }^{(20)}$, all 518 patients with GTP 1 were treated with Peg-IFN alfa $2 \mathrm{a}$, which presented high serum levels of LDL in baseline, and higher SVR rates when compared to those who presented low rates of serum LDL. Moreover, it has been observed that this response to treatment can be improved in genotype 1 patients with elevated LDL serum levels in baseline and in patients who exhibit healing difficulty when they are treated with high doses of pegylated interferon 2a plus ribavirin.

The role played by the HCV genotype in the formation of hepatic steatosis is known. Whereas GTP 3 has a direct effect in steatosis, related to the viral load level, in GTP 1 and GTP 2 steatosis, it seems to be secondary, related to the increase of insulin resistance and to the body mass index ${ }^{(7,21)}$. For this reason, we assessed whether the HCV genotype could influence the lipid serum level behavior. We did not find a difference in the referred assessment. Nevertheless, the DELTA TC and DELTA LDL were higher in genotype 3 patients, although DELTA triglycerides were lower in genotype 1 . Mark et al. ${ }^{(19)}$, observed which DELTA cholesterol levels were higher in GTP 3 than in GTP 1 and $2(0.028$ and 0.019 respectively).

\section{CONCLUSION}

The effect in serum levels of lipids differed between the two schemes of treatment.TC and LDL decreased in G-PR, and TGs increased, whereas in G-DAAs the opposite occurred. The treatment with DAAs was associated with an increase in TC and LDL serum levels and with a decrease in TGs, regardless of whether SVR was reached. The DELTA lipids did not present any difference when categorized by genotype (GTP 1 and GTP 3), maybe because of possible DAAs action in lipid behavior instead of virus action. Other studies could be performed with longer follow-up periods to demonstrate whether the non-eradication of the virus could be associated with the lipid levels prior to the use of DAAs.

\section{ACKNOWLEDGEMENTS}

Study Group of HCV: Liciana Vaz Silveira, Vanessa Nogueira da Silva Paixão, Mari Nilce Peres, Walnei Fernandes Barbosa, Mariana de Souza Dorna, Rejane Maria Tommasini Grotto, Maria Inês de Moura Campos Pardini. All of them performed the reasearch.

\section{Authors' contribution}

Andrade VG: designed the study and wrote the paper. Yamashiro FS, Oliveira CV, Kurozawa LL, Moreira A: performed the reasearch. Silva GF: designed the study, wrote the paper and revised the manuscript for final submission. 
Andrade VG, Yamashiro FS, Oliveira CV, Kurozawa LL, Moreira A, Silva GF. Aumento dos lípides durante tratamento para VHC: ação do vírus ou da medicação? Arq Gastroenterol. 2018;55(2):184-7.

RESUMO - Contexto - A interação entre lípides séricos e infecção pelo vírus C já é bem conhecida, assim como o comportamento dos níveis séricos daqueles durante o tratamento com Peg-IFN/RBV. No entanto, com antivirais de ação direta (AADs) este comportamento ainda não está claro. Objetivo - Comparar os níveis séricos de lípides entre pacientes tratados com Peg-IFN/RBV e AADs e avaliar os lípides na resposta virológica sustentada (RVS) com AADs. Métodos - Estudo retro prospectivo comparando o comportamento dos níveis séricos de colesterol total (CT), lipoproteínas de baixa densidade (LDL) e triglicérides (TG) durante o tratamento com AADs (G-AADs) e um grupo histórico de controle Peg-IFN/RBV (G-PR). Coorte, estudo prospectivo, para estudar o comportamento dos lípides na RVS com AADs. Os dados foram coletados no início do tratamento (baseline: t-base) e na décima segunda semana de tratamento (t-12) para G-AADs e na vigésima quarta semana de tratamento (t-24) para G-PR para a análise comparativa entre os dois grupos. Na avaliação de coorte, as amostras foram coletadas no t-base e na décima segunda semana após o término do tratamento (t-RVS). Delta lípides: diferença entre lípides em t-12/t-24 menos t-base para comparação entre os grupos G-PR e G-AADs e t-RVS menos t-base para análise de lípides na RVS. A análise estatística descritiva, os testes não paramétricos de Kruskal Wallis e Wilcoxon foram utilizados para comparar o delta lípides dos grupos. O valor de $P$ considerado foi de 0,05 . Resultados - Na avaliação entre os grupos G-PR e G-AADs, incluímos 63 e 121 pacientes, respectivamente. Os grupos não diferiram um do outro (IMC, sexo, genótipo, fibrose, colesterol total, LDL e TG), exceto por idade $(50,38 \pm 10,44$ vs $56 \pm 9,69, P=0,0006)$. Observamos uma diminuição nos níveis de CT e LDL e um aumento de TG no G-PR, no G-AADs ocorreu o oposto ( $\triangle \mathrm{CT}-13,9 \pm 34,5$ vs $4,12 \pm 34,3 P=0,0005, \Delta$ LDL $-7,16 \pm 32$ vs $10,13 \pm 29,92, P=0,003, \Delta$ TG $4,51 \pm 53,7$ vs $-8,24 \pm 49,93, P=0,0025)$. $\mathrm{Na}$ análise de coorte, foram incluídos 102 pacientes, $70 \%$ homens e $56 \% \mathrm{~F} 4$. Noventa e cinco deles atingiram a RVS. Observamos um aumento de CT e LDL e uma diminuição de TG em ambos os grupos (RVS e não RVS), sem diferença estatística ( $\Delta$ CT $P=0,68 ; \Delta$ LDL $P=0,69 ; \Delta$ TG $P=0,43$ ). Não encontramos diferença significativa na avaliação dos deltas pelos genótipos 1 e $3(\Delta \mathrm{CT}+29,7 \pm 40,2$ vs $+13,4 \pm 30,3, P=0,06 ; \Delta$ LDL $+21,4 \pm 28,6$ vs $+16,6 \pm 31,3, P=0,41 ; \Delta$ TG -3,6 $\pm 60,6$ vs $-0,7 \pm 40, P=0,91$ ). Conclusão $-\mathrm{O}$ nível de lípides séricos diferiu durante o tratamento com Peg-IFN/RBV e AADs. O tratamento com AADs foi associado a um aumento de CT e LDL e uma diminuição de TG, independentemente da RVS.

DESCRITORES - Hepatite C. Metabolismo dos lipídeos. Análise virológica. Interferon-alfa. Antivirais, uso terapêutico.

\section{REFERENCES}

1. Lavanchy D. Evolving epidemiology of hepatitis C virus. Clin Microbiol Infect. 2011;17:107-15. doi: 10.1111/j.1469-0691.2010.03432.x.

2. Moucari R, Asselah T, Cazals-Hatem D, Voitot H, Boyer N, Ripault MP, et al. Insulin resistance in chronic hepatitis $C$ : association with genotypes 1 and 4, serum HCV RNA level, and liver fibrosis. Gastroenterology. 2008;134:416-23. doi: 10.1053/j.gastro.2007.11.010.

3. Negro F. Abnormalities of lipid metabolism in hepatitis $\mathrm{C}$ virus infection. Gut. 2010;59: 1279-128. doi: 10.1136/gut.2009.192732.

4. Wasley A. Alter M.J. Epidemiology of hepatitis C: geographic differences and temporal trends. Semin Liver Dis. 2000;20:1-16.

5. Kiyosawa K, Sodeyama T, Tanaka E, Gilbo Y, Yoshizawa K, Nakano Y, et al. Interrelationship of blood transfusion, non A, non B hepatitis and hepatocellular carcinoma: analysis by detection of antibody to hepatitis $\mathrm{C}$ virus. Hepatology. 1990;12:671-5.

6. Alter HJ, Seeff LB. Recovery, persistence, and sequelae in hepatitis $\mathrm{C}$ virus infection: a perspective on longterm outcome. Semin Liver Dis. 2000;20:17-35.

7. Chang ML. Metabolic alterations and hepatitis C: from bench to bedside. World J Gastroenterol. 2016;22:1461-76. doi: 10.3748/wjg.v22.i4.1461.

8. André P, Komurian-Pradel F, Deforges S, Perret M, Berland JL, Sodoyer M, et al Characterization of low- and very-low-density hepatitis C virus RNA-containing particles. J Virol. 2002;76:6919-28. doi: 10.1128/JVI.76.14.6919-6928.2002.

9. Meunier JC, Russell RS, Engle RE, Faulk KN, Purcell RH, Emerson SU. Apolipoprotein cl association with hepatitis C virus. J Virol. 2008;82:9647-9656. doi: 10.1128/ JVI.00914-08.

10. Chang KS, Jiang J, Cai Z, Luo G. Human apolipoprotein e is required for infectivity and production of hepatitis C virus in cell culture. J Virol. 2007;81:13783-93. doi: 10.1128/JVI.01091-07.

11. Benga WJ, Krieger SE, Dimitrova M, Zeisel MB, Parnot M, Lupberger J, et al. Apolipoprotein $\mathrm{E}$ interacts with hepatitis $\mathrm{C}$ virus nonstructural protein $5 \mathrm{~A}$ and determines assembly of infectious particles. Hepatology. 2010;51:43-53. doi: 10.1002/ hep. 23278.

12. Ramcharran D, Wahed AS, Conjeevaram HS, Evans RW, Wang T, Belle SH, et al. Virahep-C Study Group. Associations between serum lipids and hepatitis C antiviral treatment efficacy. Hepatology. 2010;52:854-63. doi: 10.1002/ hep.23796.
13. Ramcharran D, Wahed AS, Conjeevaram HS, Evans RW, WangT, Belle SH, et al. Serum lipids and their associations with viral levels and liver disease severity in a treatment-naïve chronic hepatitis $\mathrm{C}$ type 1-infected cohort. J Viral Hepat. 2011;18:144-52. doi: 10.1111/j.1365-2893.2010.01394.X.

14. Qing S, Ji D, Li B, Li F, Wang Y, Niu X, et al. Improvement of glucose and lipid metabolism with pegylated interferon- $\alpha$ plus ribavirin therapy in Chinese patients chronically infected with genotype $1 \mathrm{~b}$ hepatitis $\mathrm{C}$ virus. Ann Saudi Med. 2015;35:293-7. doi: 10.1.1.471.5584\&rep=rep1\&type=pdf

15. Corey KE, Kane E, Munroe C, Barlow LL, Zheng H, Chung RT. Hepatitis C virus infection and its clearance alter circulating lipids: implications for long-term follow-up. Hepatology. 2009;50:1030-7. doi: 10.1002/hep.23219.

16. Meissner EG, Lee YJ, Osinusi A, Sims Z, Qin J, Sturdevant D, et al. Effect of sofosbuvir and ribavirin treatment on peripheral and hepatic lipid metabolism in chronic hepatitis C virus, genotype 1-infected patients. Hepatology. 2015;61:790801. doi: 10.1002/hep.27424.

17. Endo D, Satoh K, Shimada N, Hokari A, Aizawa Y. Impact of interferon-free antivirus therapy on lipid profiles in patients with chronic hepatitis $\mathrm{C}$ genotype 1b. World J Gastroenterol. 2017;23:2355-2364. doi: 10.3748/wjg.v23.i13.2355.

18. Morales AL, Junga Z, Singla MB, Sjogren M, Torres D. Hepatitis C eradication with sofosbuvir leads to significant metabolic changes. World J Hepatol. 2016;8:1557-63. doi: 10.4254/wjh.v8.i35.1557.

19. Pedersen MR, Patel A, Backstedt D, Choi M, Seetharam AB. Genotype specific peripheral lipid profile changes with hepatitis C therapy. World J Gastroenterol. 2016;22:10226-31. doi: 10.3748/wjg.v22.i46.10226.

20. Harrison SA, Abdurakhmanov MD, Shiffman ML, Silva GF, Bakulin I, Mazur W, et al. Intensified Peginterferon a-2a Dosing Increases Sustained Virologic Response Rates in Heavy, High Viral Load Hepatitis C Genotype 1 Patients With High Low-density Lipoprotein. J Clin Gastroenterol. 2013;47. doi: 10.1097/ MCG.0b013e31826102eb.

21. Hézode C, Roudot-Thoraval F, Zafrani ES, Dhumeaux D, Pawlotsky JM. Different mechanisms of steatosis in hepatitis $C$ virus genotypes 1 and 3 infections. J Viral Hepat. 2004;11:455-8. 